\title{
FRACTURE MECHANICAL PROPERTIES OF ROCK- LIKE MATERIALS UNDER HALF SYMMETRIC LOADING
}

\author{
ZHI WANG ${ }^{*}$, JIAJIA ZHOU ${ }^{2}$, LONG LI $^{3}$
}

\begin{abstract}
The authors studied the fracture mechanical properties under half-symmetric loading in this paper. The stress distribution around the crack tip and the stress intensity factor of three kinds of notched specimens under half symmetric loading were compared. The maximum tensile stress $\sigma_{\max }$ of double notch specimens was much greater than that of single notch specimens and the maximum shear stress $\tau_{\max }$ was almost equal, which means that the single notch specimens were more prone to Mode II fractures. The intensity factors $K_{I I}$ of central notch specimens were very small compared with other specimens and they induced Mode I fractures. For both double notch and single notch specimens, $K_{I I}$ was kept at a constant level and did not change with the change of $a / h$, and $K_{I I}$ was much larger than $K_{I} . K_{I I}$ has the potential to reach its fracture toughness $K_{I I C}$ before $K_{I}$ and Mode II fractures occurred. Rock-like materials were introduced to produce single notch specimens. Test results show that the crack had been initiated at the crack tip and propagated along the original notch face, and a Mode II fracture occurred. There was no relationship between the peak load and the original notch length. The average value of $K_{I I C}$ was about $0.602 \mathrm{MPa} \times \mathrm{m}^{1 / 2}$, and $K_{I I C}$ was about 3.8 times $K_{I C}$. The half symmetric loading test of single notch specimens was one of the most effective methods to obtain a true Mode II fracture and determine Mode fracture toughness.
\end{abstract}

Keywords: half symmetric loading, Mode II fracture; fracture toughness, rock-like material, interaction integral method

\footnotetext{
${ }^{1}$ Dr., Zhengzhou University, School of Mechanics \& Engineering Science, No.100 Science Avenue, 450001 Zhengzhou, China, ${ }^{*}$ Corresponding author, e-mail: wangzhi@zzu.edu.cn

${ }^{2}$ Dr., Zhengzhou University, School of Mechanics \& Engineering Science, No.100 Science Avenue, 450001 Zhengzhou, China, e-mail: zhjj0771@163.com

${ }^{3}$ Mr., Zhengzhou University, School of Mechanics \& Engineering Science, No.100 Science Avenue, 450001 Zhengzhou, China, e-mail: 1363884652@qq.com
} 


\section{INTRODUCTION}

In-plane shear (Mode II) rock fractures have attracted increasing interest of researchers in mining and geological and rock engineering. A lot of test methods have been proposed to study Mode II fractures of rock and concrete, such as the four-point bending test [1-2], punch-through shear test [3-4], four-point shear [5], compression shear [6], compact tension-shear [7] and half symmetric loading test [8-10]. The test results show that Mode II fracture toughness can be obtained through a half symmetric loading test for concrete [11]. The shear stress around the crack tip is much higher than the tensile stress, which is perpendicular to the original crack face for a half symmetric loading specimen. The crack propagates along the original crack face and there is no relationship between the Mode II fracture toughness, $K_{I I C}$, and initial fracture length. However, $K_{I I C}$ increases with the increase of the length and the decrease of the height of the specimens. It is therefore suggested that the half symmetric loading test would be a potential effective method to determine Mode II fracture toughness. In this paper, we use white cement to simulate rock-like materials and specimens with a central notch, double edge notches, and a single edge notch under half symmetric loading to study the fracture mechanical properties.

\section{EXPERIMENT SCHEME}

The experimental rock-like materials were produced by white cement and the mechanical parameters such as tensile strength, $\sigma_{t}$, compressive strength , $\sigma_{c}$, Elastic modulus, $E$, Poisson ratio, $\mu$, Mode I fracture toughness, and $K_{I C}$, are listed in Table 1. As shown in Figure 1, specimens with a central notch, double edge notches, and a single edge notch were prepared. Two cushion blocks were used to apply half symmetric loading. The specimen was of a rectangular shape measuring $70 \mathrm{~mm} \times 70 \mathrm{~mm} \times 30 \mathrm{~mm}$. Notches were prefabricated and the crack length, $2 a$, was about $20 \mathrm{~mm}$. The electric hydraulic servo testing machine was introduced and the loading rate was set at $5 \mathrm{~mm} / \mathrm{min}$. The peak value of the load, $P_{M}$ was recorded during the experiment. 


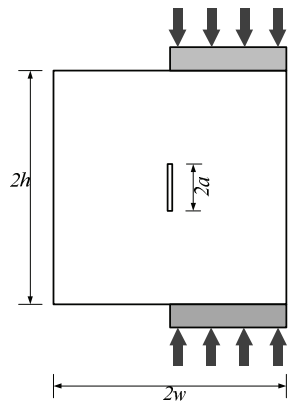

(a) Central notch

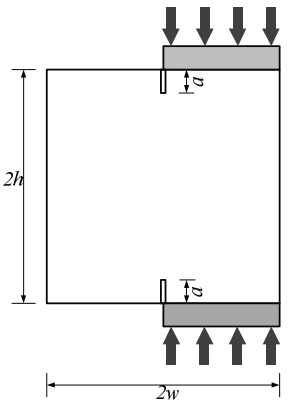

(b) Double notch

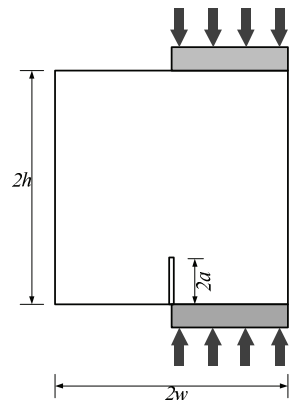

(c) Single notch

Fig. 1. Specimens and loading

Table 1. Mechanical parameters

\begin{tabular}{|c|c|c|c|c|}
\hline$\sigma_{t}(\mathrm{MPa})$ & $\sigma_{c}(\mathrm{MPa})$ & $E(\mathrm{GPa})$ & $\mu$ & $K_{I C}\left(\mathrm{MPa} \times \mathrm{m}^{1 / 2}\right)$ \\
\hline 2.04 & 24.261 & 4.68 & 0.22 & 0.158 \\
\hline
\end{tabular}

\section{FINITE ELEMENT SIMULATION}

The stress intensity factor (SIF) is an important index of brittle fractures which consider the singularity of the crack tip stress and effectively reflect the strength of the elastic stress field of the crack tip [12-13]. In comparison to the traditional displacement extrapolation method, the interaction integral method offers better accuracy, fewer mesh requirements, and ease of use [1417].

An auxiliary field of the crack tip is established to separate and obtain the Mode I and Mode II stress intensity factors in the real field for the interaction integral method. Around the crack tip, the auxiliary field must satisfy the equilibrium conditions, the physical equations, and the geometric relationship of any possible displacement field and stress field [18].

The interaction integral is defined as:

$$
I=-\int_{V} q_{i, j}\left(\sigma_{k i} \varepsilon_{k i}^{a u x} \delta i j-\sigma_{k j}^{a u x} u_{k, i}-\sigma_{k j} u_{k, i}^{a u x}\right) d V / \int_{S} \delta q_{n} d S
$$

where: 
$\sigma_{k i}, \sigma_{k j}, u_{k, i}$-the stress, strain, and displacement, $\sigma_{k j}^{a u x}, u_{k, i}^{a u x}$-the stress, strain, and displacement of the auxiliary field, $q_{i, j}$ - the crack-extension vector.

The interaction integral is associated with the stress-intensity factors as:

$$
I=\frac{2}{E^{*}}\left(K_{I} K_{I}^{a u x}+K_{I I} K_{I I}^{a u x}\right)+\frac{1}{G} K_{I I I} K_{I I I}^{a u x}
$$

where:

$K_{I}, K_{I I}, K_{I I I}$ - Mode I, II, and III stress intensity factors, $K_{I}^{a u x}, K_{I I}^{a u x}, K_{I I I}^{a u x}-$ auxiliary Mode I, II, and III stress intensity factors, $E$ - Young's modulus, $E^{*}=E$ for plane stress and $E^{*}=E /\left(1-\mu^{2}\right)$ for plane strain, $\mu$ - Poisson's ratio, $\mathrm{G}$ - shear modulus.

For the plane problem, $K_{I I I}$ can be ignored and $K_{I}^{a u x}=1, K_{I I}^{a u x}=0, K_{I}^{a u x}=0, K_{I I}^{a u x}=1$. The Mode I and Mode II stress intensity factors can be obtained through the two interaction integral calculation:

$$
K_{I}=\frac{E^{*}}{2} I_{1}, K_{I I}=\frac{E^{*}}{2} I_{2}
$$

The interaction integral method of finite element software ANSYS was adopted. The mesh for the different type specimens is shown in Figure 2. The singular element of the crack tip and the plane183 element of the non-crack zone are introduced separately. The value of loading is set to $1 \mathrm{MPa}$.

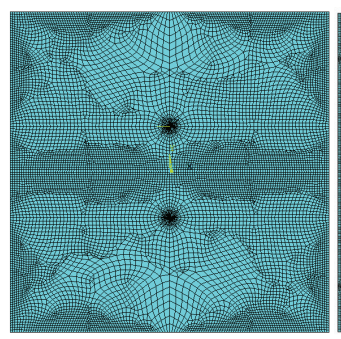

(a) Central notch

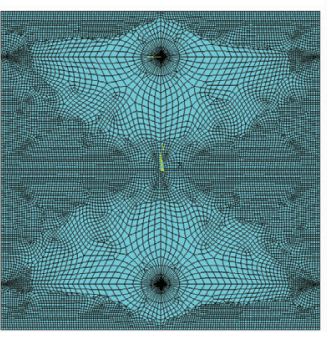

(b) Double notch

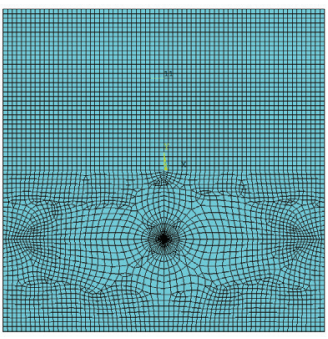

(c) Single notch

Fig. 2. Meshing 
Figure 3 and Figure 4 are tensile and shear stress contours. It can be seen from the figure that the maximum tensile stress $\sigma_{\max }$ and maximum shear stress $\tau_{\max }$ did not occur at the crack tip for central notch specimens and had a negative effect due to stress concentration. The ultimate destruction caused by sustained loading may be compression failure. The $\sigma_{\max }$ and $\tau_{\max }$ were shown at the crack tip for double notch specimens and only $\tau_{\max }$ was shown at the crack tip for single notch specimens. The $\sigma_{\max }$ of double notch specimens was much greater than that of single notch specimens in the case of crack length $2 a$. However, the maximum shear stress values were almost equal, which means that the single notch specimens were more prone to Mode II fractures.

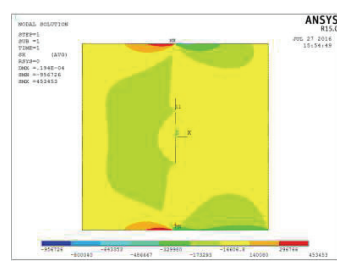

(a) Central notch

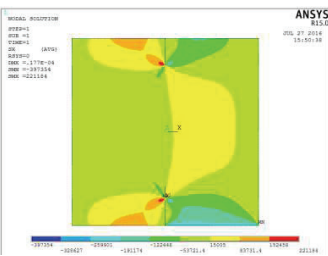

(b) Double notch

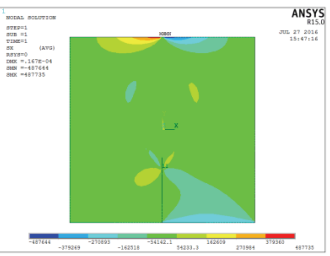

(c) Single notch

Fig. 3. Tensile stress

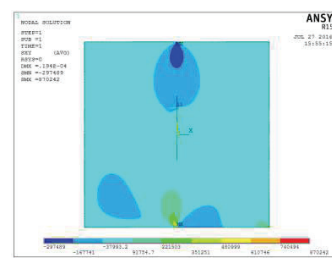

(a) Central notch

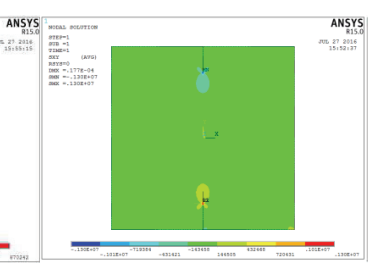

(b) Double notch

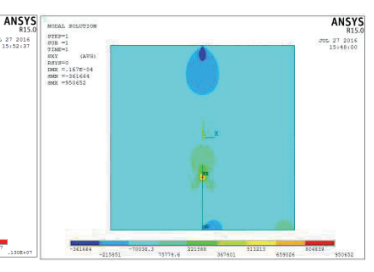

(c) Single notch

Fig. 4. Shear stress

The results for the three different specimens are listed in Table 2. For central notch specimens, the stress concentration was not obvious under half symmetric loading. Intensity factors $K_{I}, K_{I I}$, and the $K_{I I} / K_{I}$ ratio were increased with the increase of $a / h$ (see Figure 5). But $K_{I I}$ was very small compared with other specimens and it was difficult for a Mode II fracture to occur because of the lower tensile strength of brittle materials. For both double notch and single notch specimens, $K_{I I}$ was kept at a constant level and did not change with the change of $a / h$. For double notch specimens, $K_{I}$ increased first and then decreased, and $K_{I I} / K_{I}$ decreased first and then increased with the increase of $a / h$. For single notch specimens, $K_{I I}$ was 1248 times as much as $K_{I}$ when $a / h=0.5$, and $K_{I I}$ has the potential to reach fracture toughness $K_{I I C}$ before $K_{I}$ and a Mode II fracture occurred. Consequently, the single 
notch specimens should be adopted to carry out shear fracture toughness testing and to determine Mode II fracture toughness $K_{\text {IIC }}$.

Table 2. Results of stress intensity factors $K_{I}$ and $K_{I I}$

\begin{tabular}{|c|c|c|c|c|c|}
\hline Type & $2 a(\mathrm{~mm})$ & $a / h$ & $K_{I}\left(\mathrm{kPa} \times \mathrm{m}^{1 / 2}\right)$ & $K_{I I}\left(\mathrm{kPa} \times \mathrm{m}^{1 / 2}\right)$ & $K_{I I} / K_{I}$ \\
\hline \multirow{5}{*}{ Central notch } & 10 & 0.14 & 0.46 & 1.74 & 3.79 \\
\hline & 15 & 0.21 & 0.55 & 2.94 & 5.32 \\
\hline & 20 & 0.29 & 0.63 & 4.44 & 7.04 \\
\hline & 25 & 0.36 & 0.70 & 6.28 & 8.99 \\
\hline & 35 & 0.50 & 0.81 & 11.35 & 14.08 \\
\hline \multirow{5}{*}{ Double notch } & 10 & 0.14 & 0.19 & 41.40 & 217.57 \\
\hline & 15 & 0.21 & 1.34 & 42.84 & 31.94 \\
\hline & 20 & 0.29 & 1.43 & 43.73 & 30.54 \\
\hline & 25 & 0.36 & 1.18 & 44.23 & 37.49 \\
\hline & 35 & 0.50 & 0.57 & 44.10 & 77.20 \\
\hline \multirow{5}{*}{ Single notch } & 10 & 0.14 & 1.45 & 43.84 & 30.16 \\
\hline & 15 & 0.21 & 0.89 & 44.91 & 50.72 \\
\hline & 20 & 0.29 & 0.37 & 45.30 & 123.43 \\
\hline & 25 & 0.36 & 0.10 & 45.20 & 472.85 \\
\hline & 35 & 0.50 & 0.03 & 43.44 & 1248.87 \\
\hline
\end{tabular}




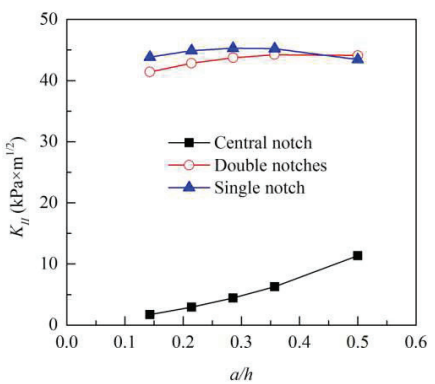

(a) $K_{I I}$

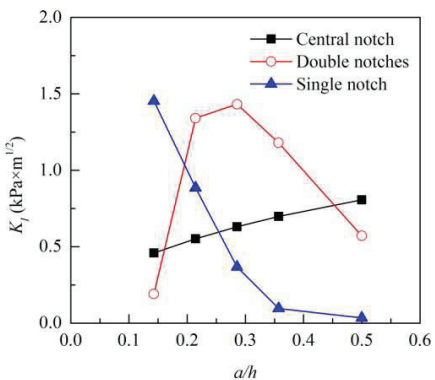

(b) $K_{I}$

Fig. 5. Relationship between stress intensity factors and $a / h$

\section{EXPERIMENTAL RESULTS AND ANALYSIS}

In order to verify the results of finite element calculation and obtain a true Mode II fracture, single notch and double notch specimens under half symmetric loading were adopted to determine the Mode fracture toughness of rock-like materials. The strain distribution of the crack tip was measured on the surface also (see Figure 6). Specimens of the same size as those used with the finite element method were used here as well.
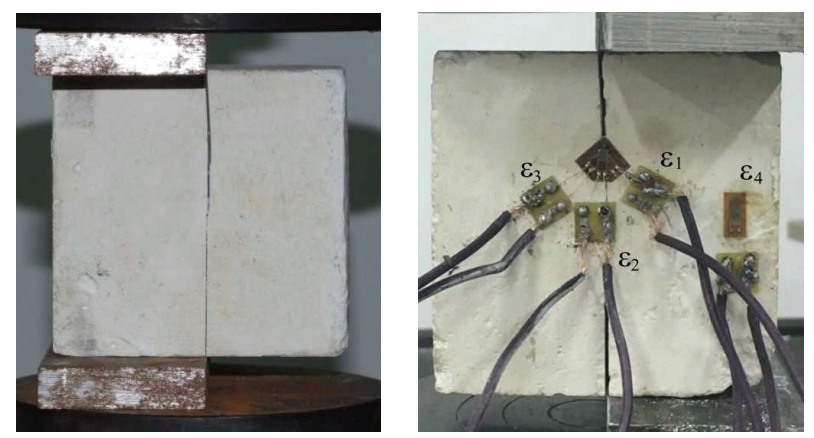

Fig. 6. Loading and strain gauge Strain gauge arrangement

Figure 7 shows the fracture trajectory of specimens under half symmetric loading with different notch lengths. It can be seen from the figure that the crack initiated at the crack tip, propagated along the original notch face, and formed a main crack with an increase of the load. Other 
longitudinal cracks occurred and the specimens were eventually destroyed by compression loading. There was no relationship between the peak load and the original notch length, which is in agreement with the calculation results of the FEM. The average value of $K_{I I C}$ was about 0.602 $\mathrm{MPa} \times \mathrm{m}^{1 / 2}$, and $K_{I I C}$ was about 3.8 times that of $K_{I C}$, which is consistent with the well-known conclusion, $K_{I I C} / K_{I C}=2 \sim 4$. The half symmetric loading test of single notch specimens was one of the most effective methods to obtain a true Mode II fracture and determine Mode fracture toughness.

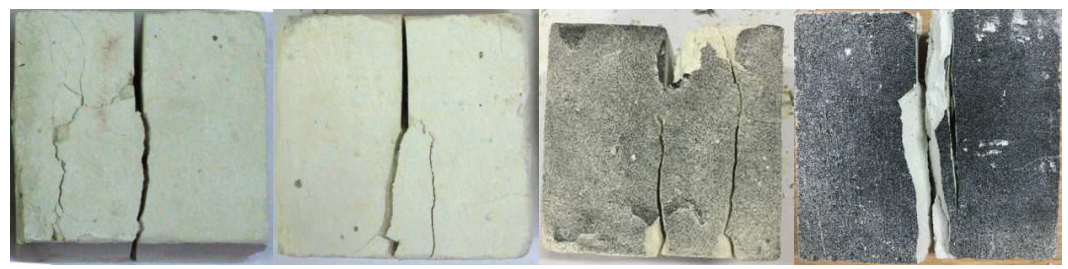

Fig. 7. Fracture trajectory

The results of the strain tests are recorded during loading. The maximum strain, $\varepsilon_{\max }$, minimum strain, $\varepsilon_{\min }$, maximum principal stress, $\sigma_{\max }$, minimum principal stress, $\sigma_{\min }$, maximum shear stress, $\tau_{\max }$, and the angle of principal stress, $\varphi$, can be obtained by Formula (4.1) to (4.4).

$$
\begin{gathered}
\varepsilon_{\max }=\frac{1}{2}\left(\varepsilon_{0^{\circ}}+\varepsilon_{90^{\circ}}\right) \pm \sqrt{\frac{1}{2}\left[\left(\varepsilon_{0^{\circ}}-\varepsilon_{45^{\circ}}\right)^{2}+\left(\varepsilon_{45^{\circ}}-\varepsilon_{90^{\circ}}\right)^{2}\right]} \\
\varepsilon_{\min } \\
\varphi=\frac{1}{2} \tan ^{-1}\left[\frac{2 \varepsilon_{45^{\circ}}-\varepsilon_{0^{\circ}}-\varepsilon_{90^{\circ}}}{\varepsilon_{0^{\circ}}-\varepsilon_{90^{\circ}}}\right] \\
\sigma_{\max }=\frac{E}{2}\left[\frac{\varepsilon_{0^{\circ}}+\varepsilon_{90^{\circ}}}{1-\mu} \pm \frac{1}{1+\mu} \sqrt{\left(\varepsilon_{0^{\circ}}-\varepsilon_{90^{\circ}}\right)^{2}+\left(2 \varepsilon_{45^{\circ}}-\varepsilon_{0^{\circ}}-\varepsilon_{90^{\circ}}\right)^{2}}\right] \\
\tau_{\max }=\frac{\sigma_{\max }-\sigma_{\min }}{2}
\end{gathered}
$$

Figure 8 shows the variation of strain and stress loading times. It can be seen that the crack tip strains (such as $\varepsilon_{1}, \varepsilon_{2}, \varepsilon_{3}, \varepsilon_{\max }, \varepsilon_{\min }$ ) were significantly greater than other location $\left(\varepsilon_{4}\right)$, meaning that the stress concentration effect of the crack tip was obvious; this would then lead to fracture (see Figure $8(\mathrm{a})$ ). The angle of the maximum principal stress and strain gauge $\varepsilon_{1}$ was about $30^{\circ}$, which agrees with the Mode I fracture under pure shear loading [19]. Thus, for the double notch specimen, the true Mode II fracture can't be obtained under half symmetric loading, which agrees with the numerical simulation results listed in Table 2 . 


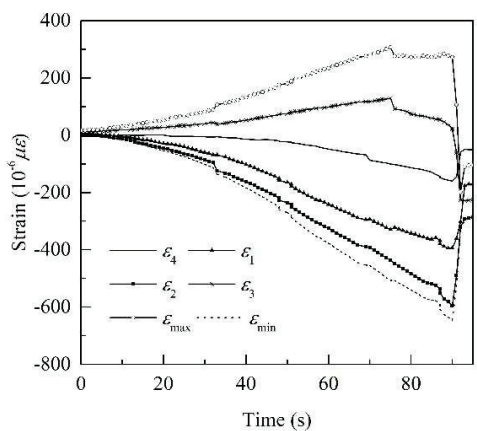

(a) strain

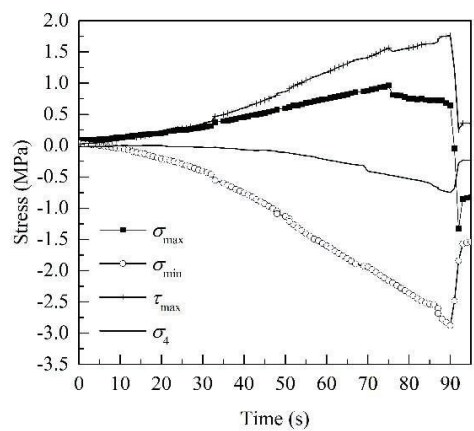

(b)stress

Fig. 8. Strain and Stress distribution

\section{Conclusions}

Fracture mechanical properties under half symmetric loading are analyzed in this paper. The stress distribution around the crack tip and stress intensity factors of three kinds of notched specimens under half symmetric loading were compared through the interaction integral method of ANSYS. The maximum tensile stress $\sigma_{\max }$ of double notch specimens was much greater than that of single notch specimens and their maximum shear stress values $\tau_{\max }$ were almost equal, meaning that the single notch specimens were more prone to Mode II fractures.

For central notch specimens, the intensity factors $K_{I I}$ were very small compared with other specimens and a Mode II fracture was not easy to obtain because of the lower tensile strength of brittle materials. For both double notch and single notch specimens, $K_{I I}$ was kept at a constant level and did not change with the change of $a / h$. For single notch specimens, $K_{I I}$ was much larger than $K_{I}$, and $K_{I I}$ had the potential to reach its fracture toughness $K_{I I C}$ before $K_{I}$ and Mode II fractures occurred.

Test results of single notch specimens under half symmetric loading show that the crack initiated at the crack tip and propagated along the original notch face, and a Mode II fracture occurred. There was no relationship between the peak load and the original notch length which is in agreement with the calculation results of the FEM. The average value of $K_{I I C}$ was about $0.602 \mathrm{MPa} \times \mathrm{m}^{1 / 2}$, and $K_{I I C}$ was about 3.8 times the value of $K_{I C}$. The half symmetric loading test of single notch specimens was 
one of the most effective methods to obtain a true Mode II fracture and determine Mode fracture toughness.

\section{ACKNOWLEDGEMENTS}

This research is supported by the National Natural Science Foundation of China (Grant No. 51404212), the Foundation for University Key Teacher by the He'nan Educational Committee (Grant No. 2016GGJS-002) and the program of China Scholarships Council (Grant No. 201608410176)

\section{REFERENCES}

1. Huang J A, Wang S: "An experimental investigation concerning the comprehensive fracture toughness of some brittle rocks", International Journal of Rock Mechanics \& Mining Science \& Geomechanics Abstracts 22(2): 99-104, 1985.

2. Schlangen E, Mier J G M V, "Crack propagation in sandstone: Combined experimental and numerical approach", Rock Mechanics \& Rock Engineering 28(2): 93-110, 1995.

3. Petit J P, "Normal stress dependent rupture morphology in direct shear tests on sandstone with applications to some natural fault surface features", International Journal of Rock Mechanics \& Mining Science \& Geomechanics Abstracts 25(6) :411-419, 1988.

4. Watkins J, "Fracture toughness test for soil-cement samples in mode II", International Journal of Fracture 23(4):135-138, 1983.

5. Bazant Z P, Pfeiffer P A, "Shear fracture tests of concrete", Materials and Structures 19(2):111-121, 1986.

6. Zhi Wang, Jianhua Hou, Chaoya Wang, Fei Yang, "An Implementation Method of Shear Plane Fracture of Multi-Crack Rock Under Compression Shear Loading”, Electronic Journal of Geotechnical Engineering (21.12) : 4595-4602, 2016

7. Lo K W, Gong Y B, Tamilselvan T, "A proposed specimen for KIIC testing", International Journal of Fracture 124(3/4):127-137, 2003.

8. Shen Xinjin, Feng Jinlong, Dai Shuhong, "Study on influence of boundary conditions on results of four point shear concrete spekles experiments", Chinese Journal of Rock Mechanics and Engineering 27(2): 3528-3534, 2008.

9. Xu Shilang, Zhao Yanhua, "Numereical simulation of mode II fracture and failure processes in concrete by 3dimensional nonlinear FEM", Journal of Hydroelectric Engineering 23(5):15-21, 2004.

10. Deng Aiming, Guo Lianmeng, Xu Daoyuan, "Comparative research on fracture toughness KIIC of two types of mode-II concrete specimens", Journal of disaster prevention and mitigation engineering 33(2):190-193, 2013.

11. Hu Shaowei Hu Liang, "Comparative study on shear fracture process of concrete with two different loading methods", China Civil Engineering Journal 49(6):25-31, 2016.

12. Chen Z Z, Tokaji K, "Effects of particle size on fatigue crack initiation and small crack growth in SIC particulate-reinforced aluminum alloy composites", Materials Letters 58:2314-2321, 2004.

13. Liu X Y, Xiao Q Z, Karihaloo B L, "XFEM for direct evaluation of mixed mode SIFs in homogeneous and bimaterials", International Journal for Numerical Methods in Engineering 59(8):1103-1118, 2004. 
14. Daimon, Ryutaro, Okada, Hiroshi, "Mixed-mode stress intensity factor evaluation by interaction integral method for quadratic tetrahedral finite element with correction terms", Engineering Fracture Mechanics, 115:22-42, 2014

15. Chiaramonte Maurizio M, Shen Yongxing, KeerMLeon M, Lew Adrian J, "Computing stress intensity factors for curvilinear cracks", International Journal for Numerical Methods in Engineering 104(4):260-296, 2015.

16. Kim J H, Paulino G H, "The interaction integral for fracture of orthotropic functionally graded materials: Evaluation of stress intensity factors", International Journal of Solids and Structures 40:3967-4001, 2003.

17. Amit, K.C., Kim, J.-H, "Interaction integrals for thermal fracture of functionally graded materials", Engineering Fracture Mechanics 75: 2542-2565, 2008.

18. GONG Jing-quan, ZHANG Shao-qin, LI He, ZHANG Chen-yu, "Computation of the Stress Intensity Factor Based on the Interaction Integral Method", Journal of Nanchang Hangkong University: Natural Sciences 29(1):42-48, 2015

19. WANG Zhi, RAO Qiuhua, XIE Haifeng, "Experimental study on time-dependent stress and strain of in-plane shear (Mode II) fracture process of rock", Journal of Central South University of Technology, 15(s1): 496-499, 2008 .

\section{LIST OF FIGURES AND TABLES:}

Fig. 1. Specimens and loading

Rys. 1. Próbki i obciążenie

Fig. 2. Meshing

Rys. 2. Zazębianie

Fig. 3. Tensile stress

Rys. 3. Naprężenie rozciągające

Fig. 4. Shear stress

Rys. 4. Naprężenie ścinające

Fig. 5. Relationship between stress intensity factors and $a / h$

Rys. 5. Związek pomiędzy współczynnikami intensywności naprężenia i $a / h$

Fig. 6. Loading and strain gauge Strain gauge arrangement

Rys. 6. Ładowanie i tensometr. Ustawienie tensometru

Fig. 7. Fracture trajectory

Rys. 7. Trajektoria pęknięć

Fig. 8. Strain and Stress distribution

Rys. 8. Rozkład odkształceń i naprężeń

Tab. 1. Mechanical parameters

Tab. 1. Parametry mechaniczne

Tab. 2. Results of stress intensity factors $K_{I}$ and $K_{I I}$

Tab. 2. Wyniki współczynników intensywności naprężenia $K_{I} K_{I I}$ 


\section{FRACTURE MECHANICAL PROPERTIES OF ROCK-LIKE MATERIALS UNDER HALF SYMMETRIC LOADING}

\section{Streszczenie:}

Slowa kluczowe: obciążenie pótsymetryczne, pęknięcie w trybie II, odporność na kruche pękanie, materiat skalny, metoda integralnej interakcji

W niniejszej pracy przedstawiono właściwości mechaniczne pękania materiałów skalnych pod półsymetrycznym obciążeniem, w wyniku połączenia analizy teoretycznej, symulacji numerycznych oraz badań eksperymentalnych. W celu ujawnienia mechanizmu uszkodzenia, przygotowano trzy rodzaje próbek z karbem pod półsymetrycznym obciążeniem i zbadano rozkład naprężeń wokół pęknięcia podczas procesu obciążenia. Przyjęto metodę integralnej interakcji oprogramowania elementów skończonych ANSYS w celu obliczenia współczynnika intensywności naprężenia (SIF). Ponadto, wprowadzono pojedynczy element pęknięcia oraz element płaszczyzny 183 w strefie bez pęknięć. Zgodnie z analizą numeryczną i wynikami badań eksperymentalnych, maksymalne naprężenie rozciągające podwójnych próbek z karbem okazało się znacznie większe niż w przypadku pojedynczych próbek z karbem, a ich maksymalne naprężenie ścinające było prawie takie samo, co oznacza, że pojedyncze próbki z karbem były bardziej podatne na pęknięcie w trybie II. Współczynniki intensywności KII środkowych próbek z karbem były bardzo niskie w porównaniu z innymi próbkami oraz tymi, które wywoływały pęknięcia w trybie I. Zarówno w przypadku próbek z podwójnym i pojedynczym karbem, KII zostało utrzymane na stałym poziomie i nie uległo zmianie wraz ze zmianą $\mathrm{a} / \mathrm{h}$, a ponadto KII było znacznie większe niż KI. KII może potencjalnie osiągać odporność na kruche pękanie KIIC przed KI. W rezultacie mamy do czynienia $\mathrm{z}$ pęknięciami w trybie II. Wprowadzono materiały skalne $\mathrm{w}$ celu wytworzenia próbek $\mathrm{z}$ pojedynczym karbem. Pęknięcie rozpoczęło się na samej górze i rozprzestrzeniało się wzdłuż pierwotnej powierzchni karbu, w wyniku czego wystąpiło pęknięcie w trybie II. Nie zaobserwowano zależności pomiędzy szczytowym obciążeniem i oryginalną długością karbu. Średnia wartość KIIC była około 3,8 razy większa niż wartość KIC. Pęknięcia w górnej części były znacznie większe niż w innym miejscu, co oznacza, że koncentracja naprężeń pęknięcia w górnej części była oczywista, co z kolei może prowadzić do pęknięcia. Kąt maksymalnego głównego naprężenia wyniósł około $30^{\circ}$, co było zgodne z pęknięciem w trybie I w warunkach czystego obciążenia ścinającego. Badanie półsymetrycznego obciążenia próbek z pojedynczym karbem okazało się być jedną z najskuteczniejszych metod uzyskiwania prawdziwego pęknięcia w trybie II i określenia odporności na kruche pękanie. 